\title{
Panik Bozukluğu Olan Hastaların Yakınları İçin Bir Rehber
}

Doç. Dr. Eylem ÖZTEN

Doç. Dr. Gül ERYILMAZ 


\title{
(C) Copyright 2020
}

Bu kitabın, basım, yayın ve satış hakları Akademisyen Kitabevi A.Ş.'ne aittir. Anılan kuruluşun izni alınmadan kitabın tümü ya da bölümleri mekanik, elektronik, fotokopi, manyetik kağıt ve/veya başka yöntemlerle çoğaltılamaz, basılamaz, dağıtılamaz. Tablo, şekil ve grafikler izin alınmadan, ticari amaçh kullanılamaz. Bu kitap T.C. Kültür Bakanlı̆̆ bandrolü ile satılmaktadır.

ISBN

978-625-7106-58-0

\section{Kitap Ad1}

Panik Bozukluğu Olan Hastaların Yakınları İçin Bir Rehber

\author{
Yazarlar \\ Eylem ÖZTEN \\ Gül ERYILMAZ
}

Yayın Koordinatörü

Yasin Dilmen

Sayfa ve Kapak Tasarımı

Akademisyen Dizgi Ünitesi

Yayıncı Sertifika No

47518

Baskı ve Cilt

Vadi Matbaacıllk

Bisac Code

PSY000000

\section{GENEL DAĞITIM}

Akademisyen Kitabevi A.Ş.

Halk Sokak 5 / A

Yenişehir / Ankara

Tel: o312 4311633

siparis@akademisyen.com

\section{www . a kade misyen.com}




\section{ÖNSÖZ}

\section{"Hayal gücünü kullanmanın en iyi yolu yaratıcılıktır. Hayal gücünün en kötü kullanımı ise kaygıdır.”}

\section{Deepak Chopra}

Korku ve kayg1, insanoğlunun baş etmek zorunda olduğu en temel duygulardan biridir. Beyinde biyolojik belirlenmişlik içinde olan ve temellerini yaşamın içinden alan bu duygular bir yanı ile yaşamı devam ettirmek için gerekli iken bir yanı ile de yaşamı tehdit edebilir. Özellikle bu iki duygu ile savaşmak kişinin kendisi ile savaşmak anlamına gelir ki oldukça zordur. Bu nedenle kaygı ve korku ile yaşam ve bu yaşantıya şahit olmak öğretici olabileceği gibi yıkıcı da olabilir.

Bu kitapta kaygı bozuklukları nedenleri, deneyimler ve yeni tedavi gelişmeleri gözden geçirilmiştir. Bu yaşantıyı deneyimleyenlere ve yakınlarına bir rehber olması dileği ile...

Kitapta geçen hikayeler, hastalarımız tarafından yazılmış olup, onayları alınarak yayınlanmıştır.

İstanbul, 2020 


\section{iÇiNDEKILER}

Panik Atakları Geçiren Bir Kişinin Yakını Olmak ....................................2

Bu Bir Hastalık Mi? ..................................................................................8

Kayg1 (Anksiyete) ve Korku Nedir? ......................................................... 8

Kayg1 Ne Zaman Bir Problemdir? ........................................................... 11

Peki, Ne Zaman Hastalık Haline Gelir?................................................... 11

Kayg1 Bozuklukları Nelerdir? ............................................................... 15

Panik Atak Nedir? ............................................................................... 15

Panik Atak Nedir? ................................................................................. 17

Panik Atak Çeşitleri Var Mıdır? ............................................................. 17

Solunumsal Alt tip............................................................................. 17

Noktürnal Alt Tip .............................................................................. 18

Korkusuz Panik Ataklar.......................................................................... 19

Bilişsel Alt Tip ......................................................................................... 19

Vestibüler Tip.......................................................................................... 19

Panik Atak ve Panik Bozukluğu Arasındaki Fark Nedir? ..................... 21

Beklenti Anksiyetesi......................................................................... 21

Kaçınma Davranışı................................................................................ 22

Panik Bozukluğu Nasıl Başlar ? ............................................................. 33

Panik Bozukluğu Neden Ortaya Çıkar?

Altında Yatanlar Nelerdir?......................................................................... 34

Anksiyete Duyarlılığı ile Beklenti

Anksiyetesi Aynı Şey Midir? .................................................................... 36

Hangi Bireyler Bu Hastalığa Yatkındır?................................................... 37

Panik Atak Belirtileri Neler ile Karıştırılıyor? ........................................ 38

Bu Ataklar Ne Kadar Sürüyor? ............................................................. 38

Panik Atakla Birlikte Agorafobiden Bahsediliyor,

Nedir Aradaki İlişki? ............................................................................... 39

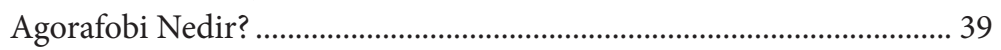

Panik Atakla Birlikte Seyreden Psikiyatrik Sorunlar Nelerdir?............ 43

Adet Döngüsü ile İlişkisi Var Mi?........................................................... 45

Panik Bozukluk Tedavisinde Beslenme ve

Egzersiz Önerileri Nelerdir ?.................................................................... 46 
Nasil Davranmalıyım? 53

Yakınınıza Panik Atak Ara Dönemlerinde

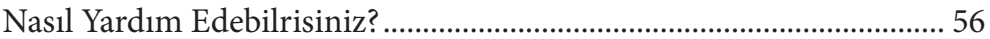

A: Panik Ataklar Stres Sonrası Olur................................................... 58

B: Panik Ataklar Delirmeye Neden Olur ............................................ 58

Yakınınıza Panik Atak Sırasında Nasıl Yardım Edebilrisiniz? ............... 59

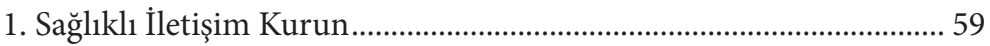

2. Durum Tespiti Yapın......................................................................... 59

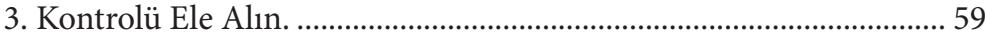

4. Dikkat Odağının Değişmesini Sağlayın. ............................................... 60

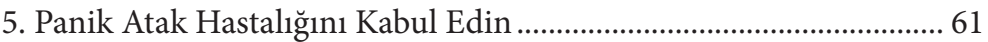

6. Beyinden Geçen Düşünceler İle İlişki Kurmayın .......................................

7. Bir Kere Deneme Sonrası Pes Etmeyin ............................................... 61

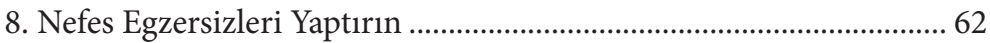

Panik Bozukluk İçin Bir Test Var M1 ?..................................................... 63

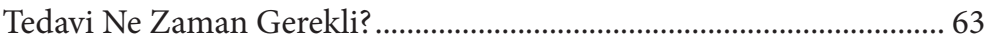

Panik Bozukluk Nasıl Tedavi Edilir?.......................................................... 65

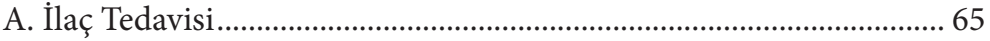

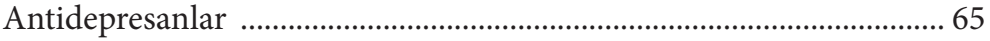

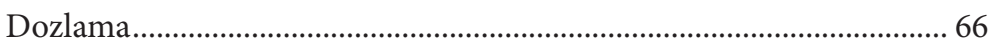

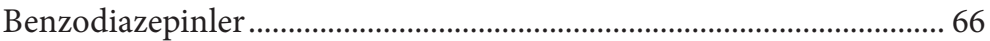

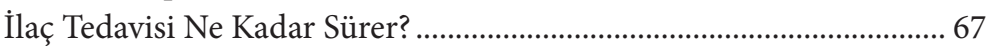

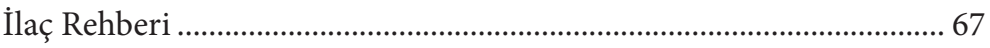

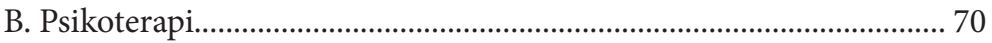

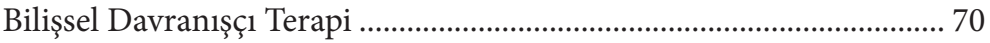

Farkındalık Temelli Bilişsel Terapi .......................................................... 71

Kabul ve Kararll1k Terapisi.................................................................... 71

Kişilerarası Psikoterapi ........................................................................ 72

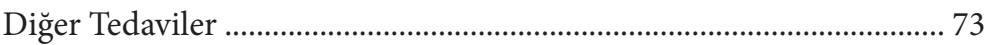

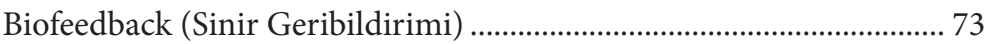

Kranial Elektroterapi (CES) .................................................................... 74

Doğru Akım Tedavisi (tDCS) .............................................................. 74

Trans Manyetik Uyarım Tedavisi .......................................................... 75 